\title{
Cross-Generational Valuing Among Peer Academic Librarians
}

\section{Gail Munde and Bryna Coonin}

This study investigated the skills, knowledge, abilities or dispositions that are most valued and respected by academic librarians, and determined how these qualities might, or might not, be associated with generational membership. Other variables included institutional classification, career length, years since first professional degree, and broad library job function. The article explains survey design, proportional random sampling method, statistical analyses and tests, and resulting findings that may have implications for recruitment, mentoring, succession planning, and for assisting in the transmission of knowledge among academic librarians, especially from career mature librarians to their younger colleagues.

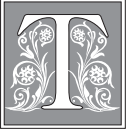

his study addresses a gap in the research concerning generational roles in the academic library workforce, particularly with regard to Millennials. There are a number of reports on generational diversity and ageism in librarianship, ably summarized by Lancaster in 2003, Hutley and Solomon in 2004, Gordon in 2006, Martin in 2006, and Chu in 2009. ${ }^{1}$ Empirical research concerning generational differences in the workplace does exist within the general management literature, as examined by Twenge in 2010, but rigorous empirical research is not available on how intergenerational colleagues actually relate to one another in the academic library work setting. ${ }^{2}$ Should we assume that the intergenerational differences represented in the management literature automatically apply to academic librarians? Rather than accept these assumptions without examination, the study investigated who academic librarians value among their colleagues, why the colleague is valued, and the generational relationship of the evaluator and the valued colleague. The subjects' institutional classification, career length, years since first professional degree, and broad library job function also were examined for possible influences on generational relationships among peer librarians.

\section{Literature Review}

Neil Howe and William Strauss, authors of such titles as Generations: The History of America's Future, 1584-2069 and Millennials Rising, are credited with developing and popularizing the "generational theory," in which differences among generations are treated in a cyclical fashion. ${ }^{3}$

Gail Munde is Associate Professor, Library Science, at East Carolina University, e-mail: mundeg@ecu. edu; Bryna Coonin is Professor, Research $\mathcal{E}$ Instructional Services, in Joyner Library at East Carolina University, e-mail: cooninb@ecu.edu. (C) 2015 Gail Munde and Bryna Coonin, Attribution-NonCommercial (http://creativecommons.org/licenses/by-nc/3.0/) CC BY-NC 
The majority of the literature that follows Howe and Strauss is largely concerned with human resource-related aspects of intergenerational attitudes and work habits generally. Smola and Sutton surveyed more than 350 individuals concerning generational differences in worker values and compared their results with those of an earlier study conducted in $1974 .{ }^{4}$ Their results indicate that generational work values differ, also suggesting that work values change as workers grow older. Macky, Gardner, and Forsyth provide an introduction to a special issue of Journal of Managerial Psychology designed to critically examine the challenges facing generational research and to "provide a litmus test against which popular stereotypes can be compared." 5

While more popular than empirical in nature, Strauss and Howe's work did provide useful theoretical descriptions of generations (such as GIs, Silents, Boomers, Gen Xers, Millennials) that a number of researchers later used to frame their own research. Kowske, Rasch, and Wile use these descriptions to contribute to "the sparse empirical literature on generational differences at work," concentrating their research on Millennials. ${ }^{6}$ Their study examines generational differences in work attitudes across five generations, looking for similarities and differences of Millennials when compared to prior generations. The study finds that generational differences at work are small overall, at least with regard to work attitudes.

Munde examines the library environment in terms of managing an increasingly intergenerational workforce in libraries. ${ }^{7}$ Her discussion includes ageism, intergenerational conflict and resolution, professional development, the transfer of institutional knowledge, work/life balance, and organizational flexibility. Smith and Galbraith are concerned with motivating library staff Millennials from the standpoint of recruitment and retention. ${ }^{8}$ While each adds a meaningful contribution to the discussion, neither of these studies employs empirical research as its underpinning.

Nursing, like academic librarianship, is an increasingly technology-heavy profession also experiencing generational issues. And, as with academic librarianship, empirical research is sparse with respect to how intergenerational work colleagues actually relate to one another. In a recent doctoral dissertation from the University of Arkansas, Jobe indicates that more similarities than differences exist in the dimensions of work ethic among the three generations of nurses studied. ${ }^{9}$ As in academic librarianship, issues surrounding recruitment and retention may be affected by generational concerns. Jobe concludes that understanding generational differences, particularly in the area of work ethic, may help with recruitment and retention strategies.

\section{Research Questions}

With regard to academic librarians

1. Do generational peers most value members of their own generational group or members of other generational groups?

2. When considering a highly valued colleague, do generational groups most value the same or different characteristics?

3. If there are relationships among the generational group, the generational group of the highly valued colleague, or the most valued characteristic, do these relationships vary by institutional broad Carnegie classification and/or the library department to which librarians are assigned?

4. What, if any, intelligence might the findings suggest for assisting in the transmission of knowledge among academic librarians, especially from career-mature librarians to their younger colleagues? 


\section{Methodology}

\section{Survey Development and Sampling Technique}

The survey asked for respondents' demographic characteristics including: Chronological age group (31 years or less, 32-48 years, or 49 years or more), year the degree in librarianship was awarded, years of experience as an academic librarian (5 years or less, 6-10 years, 11-15 years, 16-20 years, or 21 or more years), the departmental assignment (administration, IT/systems, public services, special collections, or technical services), and the broad Carnegie classification of the institution(s) in which they had spent most of their professional careers (Baccalaureate, Masters I/II, Doctoral/ Research). Survey respondents were then asked to "call to mind an academic librarian [they] greatly value at the present time as highly competent and effective," and answer three questions about this valued library colleague. The first two questions were to identify the estimated age group and career department of the valued colleague. The third question asked respondents to choose only one of six characteristics that would best reflect why they valued this library colleague:

- Leading and influencing others

- Navigating the political environment to make positive change

- Facility with emerging technologies

- Having a strong work ethic and high job engagement

- Having deep knowledge of a specific discipline or subject

- Being open to innovation and flexible during periods of change

Respondents were asked to call to mind a single library colleague whom they most valued currently in terms of competence and effectiveness, and they were forced to choose only one characteristic that best reflected why they valued the library colleague. By no means do the six characteristics exclude one another, but the respondents' task was to identify a single, discriminate preference. Making a prior mental identification of a person provided focus and specificity for consideration of the subsequent question. Simply asking respondents to identify the characteristic they most valued in general would have been too abstract to make a meaningful choice. Respondents also had the opportunity to add comments about the valued library colleague.

The six characteristics were refined from many descriptors of the knowledge, skills, and abilities suggested by standards for academic librarians. An inventory of important knowledge, skills and abilities was compiled from the ACRL 2010 Environmental Scan, ASERL's Competencies for Research Librarians, and ALA's Core Competences of Librarianship. ${ }^{10}$ The initial inventory contained more than seventy items, which were then grouped into eight broad categories: leadership, administration, and management; information literacy; collection development; common and emerging technologies; core values; policy issues; understanding and working within an institution; and responsibilities of all academic librarians. These eight categories were refined further to six broad characteristics, or dispositions, that would not be specific to any professional academic library position.

Once the survey was finalized, and the study approved by the researchers' Institutional Review Board, it was deployed in pilot to a random sample of one hundred academic librarians in the pool, and eighteen valid surveys were collected. Of particular interest at this point were the comments. Respondents' comments were cross-checked with the most valued characteristic selected by the respondent to gauge the respondents' interpretation of the characteristic. Since the survey was constructed with only face validity, it was important to seek input to indicate whether the list of six characteristics was intelligible to potential survey respondents.

Most comments amplified or expanded upon the chosen characteristic or provided a practical interpretation of the characteristic. As a measure of reliability, or internal con- 
sistency of the pilot survey, Cronbach's alpha was calculated as 0.581, and the split-half correlation was 0.383 , both lower than 0.70 (which is considered the acceptable value).

Based on the results of the pilot survey and companion comments, the original wordings of two characteristics were changed to improve clarity. To better express the intent of "Navigating organization policy and politics," which could be interpreted as a self-serving or negative characteristic, the wording was changed to "Navigating the political environment to make positive change." Wording of the characteristic "Understanding the potential of emerging technologies" was changed to "Facility with emerging technologies" because "understanding" is not an observable behavior, while "facility" with technologies is overtly demonstrable. No definitions or descriptions of the six characteristics were provided in the survey.

\section{Sampling Technique}

According to the National Center for Education Statistics (NCES), the population of U.S. academic librarians working in four-year or higher institutions in 2010 was estimated at 19,862 FTE librarians working in 1,428 institutions. The NCES count was of full-time equivalents, but the headcount has been estimated as high as 29,278, including nine- and twelve-month and part- time appointments, as well as librarians working at community colleges. ${ }^{11}$ To calculate a response rate at the 0.95 confidence level, the NCES FTE figure was used as the population estimate so that associate and special-focus institutions could be eliminated from the sampling pool. Of the 1,428 institutions reported by NCES as employers of academic librarians, $275(19 \%)$ were in the broad Carnegie classification of Doctoral/Research universities, 597 (42\%) were classified as Masters I/II, and 556 (39\%) were classified as Baccalaureate. To reflect the population, both in proportion to broad Carnegie classification and to generate a valid sample size, a pool of 1,040 U.S. institutions was selected from the American Library Directory based on the availability of individual e-mail addresses for librarians. ${ }^{12}$ From this institutional pool, a list of 10,637 e-mail addresses for academic librarians working in the 1,040 institutions was compiled. From these 1,040 institutions, a proportional random sample of 736 institutions was drawn to include 140 Doctoral/ Research institutions (19\%), 309 Masters I/II institutions (42\%), and 287 Baccalaureate institutions (39\%), which approximated the actual proportion of institutional classifications within the population.

A list of 6,400 e-mail addresses for librarians working at these 736 institutions was generated and randomized, and the first 6,000 account holders (less the one hundred addresses used for the survey pilot) were e-mailed a link to the survey embedded in a cover letter.

Undeliverable e-mail addresses were replaced from the remaining 300 in the sample pool until the survey was successfully delivered to 5,954 valid e-mail addresses. A follow-up solicitation was sent two weeks later. A total of 812 respondents submitted the survey (13.6\%), and 766 surveys (12.8\%) were usable. Based on a population estimate of 19,862 and 766 valid responses, the confidence level was 0.95 , with a 3.5 percent margin of error. This meant the eventual results of the survey could be attributed to random in five out of 100 trials, and response results could vary by plus or minus 3.5 percent.

\section{General Profile of Respondents}

Of the 812 librarians who submitted the survey, forty-six surveys were unusable because of nonresponse to one or more key items or because the respondents indicated not having a graduate degree in librarianship, which, although not a requisite for librarianship, was a requisite for the survey response to be considered valid. The overall profile of the 766 valid respondents is illustrated in table 1. 


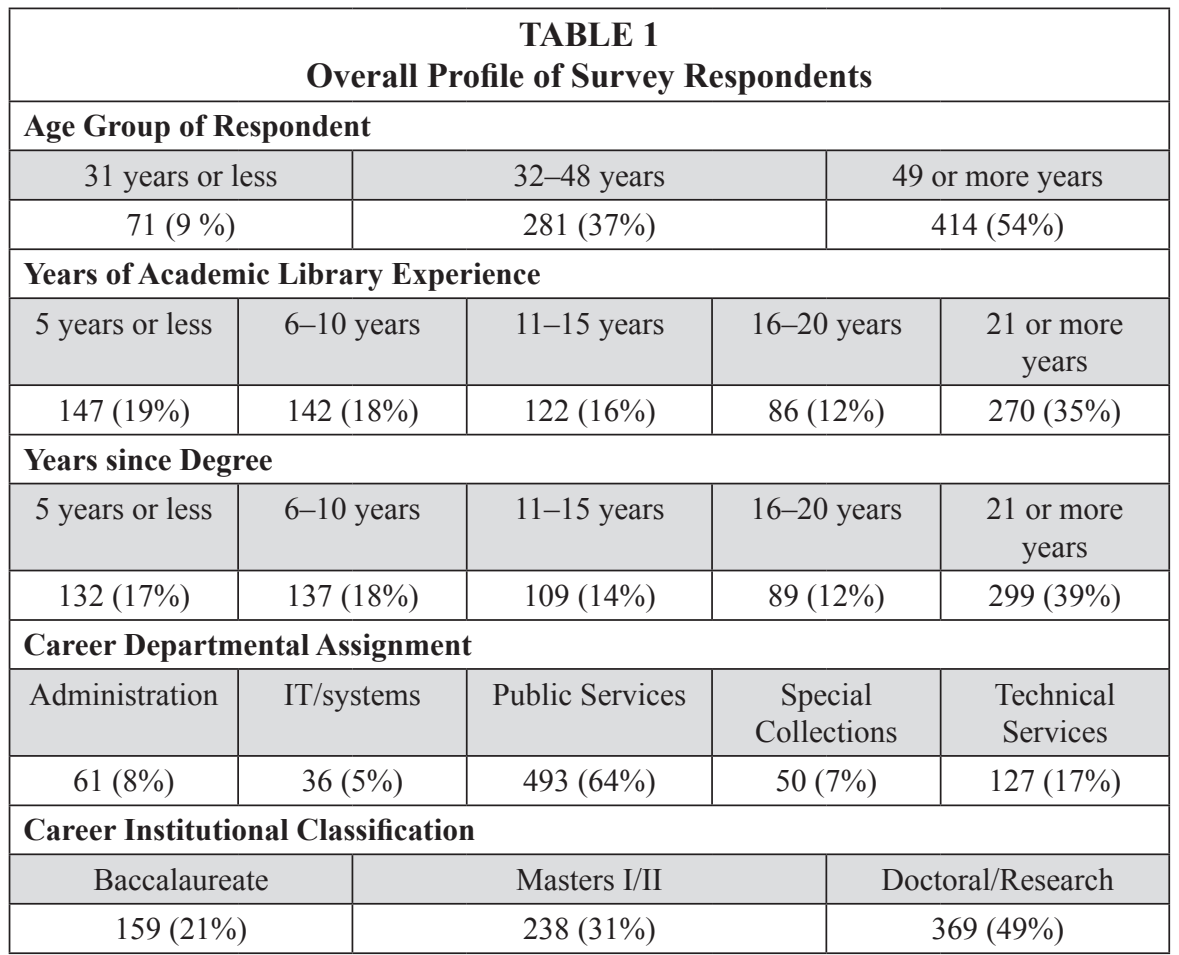

The sample appears to represent the current population of academic librarians in the workforce with regard to chronological age, institutional classification, career department, years since the award of a graduate library degree and years of professional library experience (independent variables). The dependent variables represent the valued colleague in terms of chronological age, institutional classification, career department, and most valued characteristic. When a sample of the population (that is to say, the survey respondents) closely reflects the known characteristics of the population, survey results are more likely to be generalizable to the entire population.

\section{Independent Variables}

Age

According to the ALA Office of Research and Statistics, the median age of all librarians in 2007 was forty-eight. ${ }^{13}$ Moran, Marshall, and Rathbun-Grubb in their 2010 study found the median age of academic librarians who participated in a national study also to be forty-eight. ${ }^{14}$ Forty-six percent of subjects in the present study were 48 or younger, while 54 percent were 49 or older; about 4 percent difference from the median of 48 identified in the earlier studies.

\section{Years of Experience and Years Since the Award of Degree}

The median number of years of professional academic library experience in present survey respondents would occur somewhere in the 11- to 15-year range, but just barely, as 51 percent of respondents had 16 or more years of experience. This seems to reflect the norm, and roughly comparable to an average of 17 years of experience for the 8,512 librarians reported in the 2009-2010 ARL Salary Survey. ${ }^{15}$ 
It is generally accepted that librarians enter the profession later than those of other professions; that is, as a second career, or after raising young children, or leaving work to raise young children and returning later. Chronological age, years since the award of a graduate degree in librarianship, and years of experience as a professional librarian may not fall in a linear, unbroken path. To determine the association among these as dependent variables, and check for their intervening effect on the independent variables, $X^{2 \prime}$ s produced $p$ values of $>.001$ for both age group and years since degree, and for years since degree and years of experience. Values of Cramer's $V$ were for 0.78 for age group and years since degree, and 0.58 for years since degree and years of experience. To be considered strongly associated, the value of $V$ must meet or exceed 3.0. Such high values of $V(0.78$ and 0.58$)$ indicate that the variables are redundant; that is, all three variables measure the same concept. Put simply for analytical purposes, respondents' age, years since degree, and years of experience can all be treated as the same thing.

\section{Career Department}

Little is known about the departmental assignments of academic librarians in the general population, but King and Griffiths' results of a national survey of academic librarians found that 9 percent worked in administrative positions, 21 percent worked in technical services positions, 44 percent worked in public services positions, 3 percent worked in special collections positions, and 3 percent worked in systems positions. ${ }^{16}$ The remaining 20 percent or so worked in either "other/unknown" positions, or in a library not organized by department. Among respondents to the present survey, 8 percent worked in administration, 17 percent worked in technical services, 64 percent worked in public services, 7 percent worked in special collections, and 5 percent worked in IT/systems. The disproportionate response by public services librarians in the present study could be accounted for if a significant portion of the 20 percent or so of librarians in the King and Griffiths study who reported that they worked in a library not organized by department or who reported "other/unknown" as their assignment to be public service librarians by default. If this is acceptable, then respondents to the present survey would appear comparably distributed to those in the King and Griffiths study.

\section{Career Institution Classification}

An attempt was made to reflect the known population by taking a random proportional sample of institutions by broad Carnegie classification and then randomly sampling librarians working at those institutions. The tabulation of survey respondents roughly reflected the known number of librarians working in each setting. ${ }^{17}$ The known population of librarians and the response rate by institutional classification were, respectively, Doctoral Research librarians (46\%, 49\%), Master's I/II librarians (22\%, 31\%), and Baccalaureate librarians $(11 \%, 21 \%)$. Librarians working at Master's and Baccalaureate institutions overresponded slightly, 9 percent for Master's librarians and 10 percent for Baccalaureate librarians, while Doctoral/Research librarians underresponded by 3 percent.

\section{Results and Analysis}

Because the six choices of valued characteristics were not randomized during survey administration, the total response frequencies to the choices were examined for response order effect, and none was apparent (see table 1). That is, it did not appear that choices were selected more frequently because of their order in the list, especially with regard to the first and last choices. Cronbach's alpha was calculated as a measure of survey reliability as 0.516 (lower than the calculated value from the pilot survey) and the split-half correlation was 0.532 (higher than the calculated value from the pilot survey), but both were below the acceptable value of 0.70 . 
Contingency tables were prepared for independent variables (traits of respondents) against dependent variables (traits of their valued library colleagues) and values of $p$ for the tabulations are provided in table 2.

\begin{tabular}{|l|c|c|c|}
\hline \multicolumn{4}{|c|}{ TABLE 2} \\
\hline & \multicolumn{3}{|c|}{ Values of $\boldsymbol{p}$ from $\boldsymbol{X}^{\mathbf{2}}$ Cross Tabulations } \\
\hline $\begin{array}{l}\text { Respondent } \\
\text { Variables }\end{array}$ & Age group & Department & Valued Characteristic \\
\hline Age Group & $<0.001 *$ & 0.491 & $<.001^{*}$ \\
\hline Institution Type & 0.118 & $<0.005^{*}$ & 0.847 \\
\hline Department & 0.644 & $<0.001 *$ & $0.005^{*}$ \\
\hline Years Experience & $0.001 *$ & 0.829 & $0.001^{*}$ \\
\hline Years since Degree & $0.001^{*}$ & 0.859 & $0.007^{*}$ \\
\hline *Values of $p \leq 0.05$ indicate that resulting associations would be due to chance in five or \\
fewer of 100 trials.
\end{tabular}

Contingency tables producing critical values of $X^{2}$ at $p \leq 0.05$ were then tested post hoc using either the Pearson contingency co-efficient $(C)$ or Cramer's contingency coefficient $(V)$ as appropriate to estimate the strength of the associations, and cell pairings with significant standardized residuals were identified to enlighten the research questions.

1. Do generational peers most value members of their own generational group, or members of other generational groups?

Cross-tabulation of respondents by age group (under 31, 32-48, 49 or older) and the estimated age group of the valued colleague resulted in a $X^{2}$ with a $p$ value $<0.001$, indicating that age group of the respondent was associated with age group of the valued library colleague. A Pearson contingency co-efficient $(C)$ of 0.165 indicates a low but substantive association, which means that knowing the age group of an academic librarian helps to predict the age group of the valued colleague, but is not a strong predictor.

Standardized residuals were calculated for individual cell pairings, and pairings with residuals greater than $+/-1.97$ (larger than expected by chance) are indicated in table 3 .

\begin{tabular}{|c|c|c|c|c|c|}
\hline Age G & of Respo & $\begin{array}{r}\text { TABI } \\
\text { ents and } A\end{array}$ & roup o & ued Colle & \\
\hline What do you & late to be th & urrent age & s valuec & lemic libra & \\
\hline & & Under 31 & $32-48$ & 49 or over & $\mathrm{N}$ \\
\hline $\begin{array}{l}\text { chronological } \\
\text { age today is }\end{array}$ & Under 31 & 3 & $\begin{array}{c}44 \\
2.18\end{array}$ & $\begin{array}{c}23 \\
-2.07\end{array}$ & 70 \\
\hline & $32-48$ & 16 & 142 & 127 & 285 \\
\hline & 49 or over & 14 & 163 & 238 & 415 \\
\hline & & & & 2.00 & \\
\hline & $\mathrm{N}$ & 33 & 349 & 388 & 770 \\
\hline
\end{tabular}


Standardized residuals indicate the importance of the cell to the $X^{2}$ value and, like a zscore, indicate the number of standard deviations above or below the expected cell count.

Of the three cells making important contributions to the $X^{2}$ value, two of them occurred in the row for respondents who were under 31 years of age. The positive residual of 2.18 in the cell pairing with a valued colleague being in the 32-48 age group indicates a greater result than expected, and the negative residual of -2.07 in the pairing with a valued colleague being in the 49 or over age group indicates a lesser result than expected. This suggests that academic librarians 31 years of age and younger may be likely to value library colleagues in the 32-48 age group more than they value librarians in the 49 years or more age group. The third significant residual is a positive 2.0 in the cell pairing between academic librarians in the 49 years or more age group with other library colleagues in the same age group. To answer the research question, there is a low association between the age group of the respondent and the age group of the valued colleague. Further, early career librarians may value mid-career librarians more than senior-career librarians, while senior-career librarians may value other senior career librarians more than mid- or early-career librarians.

2. When considering a highly valued colleague, do generational groups most value the same or different characteristics?

Cross-tabulation of respondents by age group (under 31, 32-48, 49 or older) and the most valued characteristic of the library colleague resulted in a $X^{2}$ with a $p$ value $<0.001$. The Cramer's $V$ of 0.16 indicates a low but substantive association between age group of the respondent and most valued characteristic of the library colleague. To be considered strongly associated, the value of $V$ must meet or exceed 3.0.

Standardized residuals were calculated for individual cells; cells with residuals greater than $+/-1.97$ are indicated in table 4 .

\begin{tabular}{|c|c|c|c|c|c|c|c|c|}
\hline & Ag & Group o & Responder & $\begin{array}{l}\text { TABLE } 4 \\
\text { ts and Mos }\end{array}$ & Valued C & aracterist & & \\
\hline & & $\begin{array}{l}\text { Keeping thi } \\
\text { that best ref }\end{array}$ & $\begin{array}{l}\text { valued acaden } \\
\text { ects why you } v\end{array}$ & $\begin{array}{l}\text { iic librarian in } \\
\text { alue this person }\end{array}$ & hind, choose o & nly ONE of th & e categories be & \\
\hline & & $\begin{array}{l}\text { Leading } \\
\text { and } \\
\text { Influencing } \\
\text { Others }\end{array}$ & $\begin{array}{l}\text { Navigating } \\
\text { the Political } \\
\text { Environment } \\
\text { to Make } \\
\text { Positive } \\
\text { Change }\end{array}$ & $\begin{array}{l}\text { Facility with } \\
\text { Emerging } \\
\text { Technologies }\end{array}$ & $\begin{array}{l}\text { Having } \\
\text { a Strong } \\
\text { Work } \\
\text { Ethic and } \\
\text { High Job } \\
\text { Engagement }\end{array}$ & $\begin{array}{l}\text { Having } \\
\text { Deep } \\
\text { Knowledge } \\
\text { of a } \\
\text { Specific } \\
\text { Discipline } \\
\text { or Subject }\end{array}$ & $\begin{array}{l}\text { Being } \\
\text { Open to } \\
\text { Innovation } \\
\text { and Flexible } \\
\text { During } \\
\text { Periods of } \\
\text { Change }\end{array}$ & $\mathrm{N}$ \\
\hline $\begin{array}{l}\text { My } \\
\text { chronological } \\
\text { age today is }\end{array}$ & $\begin{array}{l}\text { Under } \\
31\end{array}$ & 6 & 12 & 2 & $\begin{array}{l}36 \\
2.5\end{array}$ & 7 & 8 & 71 \\
\hline & $\begin{array}{l}32- \\
48\end{array}$ & 46 & 39 & 11 & 86 & $\begin{array}{c}49 \\
2.03\end{array}$ & 50 & 281 \\
\hline & $\begin{array}{l}49 \text { or } \\
\text { over }\end{array}$ & 76 & $\begin{array}{c}29 \\
-2.17\end{array}$ & 30 & 135 & 44 & 100 & 414 \\
\hline & $\mathrm{N}$ & 126 & 80 & 43 & 257 & 100 & 158 & 766 \\
\hline
\end{tabular}


One-third of all respondents identified "Having a strong work ethic and high job engagement" as the most valued characteristic. It might be that a strong work ethic and high job engagement are pre- or co-requisites for selection as the valued colleague, for without this characteristic few excel in other aspects of work. In each of the age groups, one cell pairing produced a significant standardized residual.

The residual for the cell pairing between the 31 and under age group and the characteristic of "strong work ethic and high job engagement" was +2.5 , indicating that this pairing was important in terms of contributing to the overall $X^{2}$ value. Slightly over 50 percent of respondents in this age group chose it as the most valued characteristic; more than either of the other two age groups. If, in addition to valuing this characteristic in others, early-career librarians actually emulate behaviors of the characteristic, the result would certainly counter a common social misperception that younger workers are disengaged, less responsible, or less diligent than older workers.

The residual for the cell pairing between the 32-48 age group and the characteristic of "Having deep knowledge of a specific discipline or subject" was 2.03. One interpretation is that the middle of a person's career might be devoted to developing a high level of expertise in a specialized area, and this group may value the characteristic because it represents the career task at hand. The third and potentially most important residual occurred in the cell pairing between the 49 or older age group and "Navigating the political environment to make positive change." A negative residual of -2.17 indicates the choice was selected by far fewer respondents than expected and contributed significantly to the $X^{2}$ value. This presents a potential gap for the transmission of knowledge from career-mature librarians to their more junior colleagues.

3. If there are relationships among the generational group, the generational group of the highly valued colleague, or the most valued characteristic, do these relationships vary by institutional broad Carnegie Classification and/or the library organizational division in which librarians work?

The broad Carnegie classification of the institution in which respondents had spent most of their library careers (Baccalaureate, Master's I/II, Doctoral/Research) was not associated with either the age group of the valued colleague, or the most valued characteristic of the library colleague. Cross-tabulation of the respondents' career institution by Carnegie level and the estimated age group of the valued colleague yielded a $X^{2}$ that approached but did not meet the required critical value for significance, and no claim can be made for an association between these two variables. The associated value of $p$, at 0.118 , indicated that the results would be due to random chance in 11 out of 100 trials.

Cross-tabulation for the respondents' career institution by Carnegie level and most valued characteristic of the library colleague resulted in a $X^{2}$ that did not meet the critical value for an association, and the $p$-value of 0.847 indicated the results would be due to random chance in about 85 of 100 trials. One might think that differences in purpose, culture, or values of these different types of higher education institutions would have some effect on selection of the most valued characteristic, but no association was found.

Cross-tabulation of the respondents' career institution by Carnegie level and department in which the most valued library colleague works resulted in a significant $X^{2}$ and a $p$-value of $<0.005$. A $V$ of 0.12 indicated a low association between these variables. One cell-pairing had a large residual (2.73), indicating that the pairing was important in terms of its contribution to the $X^{2}$ value, and this pairing was between respondents who spent most of their careers working in Baccalaureate institutions and their valued colleagues whose department was library administration. This could be due to undergraduate institutions having relatively smaller and flatter library organizations and more frequent opportunities for contact between librarians and library administrators, 
or perhaps due to the library director being recognized as the sole, or most influential, leader within their libraries.

If there were an association between the departmental assignment of respondents and the departmental assignment of their valued library colleagues, it was not confirmed in the present study. Although the $X^{2}$ value was significant at a $p$-value near 0.0 , the test was invalid due to the high number of cells with expected frequencies less than five. The only remedy in such cases is to combine two or more of the categories, which reduces the number of cells overall. The remedy in this case was to group the IT/systems and technical services categories into one group. Not an ideal solution to the problem, but the groups share more similarities than others: that is, both do work that is unseen by the library user, and both find solutions to technical and technological library problems. Acknowledging some potential for error, table 5 illustrates the results after combining the two groups.

\begin{tabular}{|c|c|c|c|c|c|c|}
\hline \multicolumn{7}{|c|}{$\begin{array}{c}\text { TABLE } 5 \\
\text { Departmental Assignment of Respondent and Departmental Assignment of } \\
\text { Valued Colleague }\end{array}$} \\
\hline & & \multicolumn{5}{|c|}{ This valued academic librarian currently works in } \\
\hline & & Administration & $\begin{array}{l}\text { IT/Systems } \\
\text { and } \\
\text { Technical } \\
\text { Services }\end{array}$ & $\begin{array}{l}\text { Public } \\
\text { Services }\end{array}$ & $\begin{array}{l}\text { Special } \\
\text { Collections }\end{array}$ & $\mathrm{N}$ \\
\hline \multirow{5}{*}{$\begin{array}{l}\text { Most of my } \\
\text { professional } \\
\text { career as an } \\
\text { academic } \\
\text { librarian has } \\
\text { been spent } \\
\text { working in }\end{array}$} & Administration & $\begin{array}{c}28 \\
5.08\end{array}$ & 5 & 27 & 1 & 61 \\
\hline & $\begin{array}{l}\text { IT/Systems } \\
\text { and } \\
\text { Technical } \\
\text { Services }\end{array}$ & 27 & $\begin{array}{c}61 \\
7.32\end{array}$ & $\begin{array}{c}70 \\
-3.14\end{array}$ & 5 & 163 \\
\hline & $\begin{array}{l}\text { Public } \\
\text { Services } \\
\end{array}$ & 77 & $\begin{array}{c}41 \\
-3.89\end{array}$ & $\begin{array}{l}367 \\
3.35\end{array}$ & $\begin{array}{c}9 \\
-2.55\end{array}$ & 494 \\
\hline & $\begin{array}{l}\text { Special } \\
\text { Collections }\end{array}$ & 9 & 9 & $\begin{array}{c}15 \\
-2.9\end{array}$ & $\begin{array}{c}17 \\
10.38\end{array}$ & 50 \\
\hline & $\mathrm{N}$ & 141 & 116 & 479 & 32 & 768 \\
\hline \multicolumn{7}{|c|}{$X^{2}=264.12, p \leq 0.001, \mathrm{C}=0.49$} \\
\hline
\end{tabular}

Aside from generational membership, there was a high association $(C=0.49)$ between the department in which the respondents worked and the department in which the valued colleague worked, and this was further supported by the positive standardized residuals in matching departmental cell pairings. It seems sensible to conclude that librarians more often value those in closest workplace proximity; librarians whose performance is known through direct observation and perhaps best understood by those working closely as departmental colleagues. The cells with negative residuals may indicate that there are clear divisions between public services librarians and librarians in other departments. Special collections librarians most often valued other special collections librarians but were far less likely to value public service librarians.

Public service librarians most often valued other public service librarians but were less likely to value IT/systems and technical services librarians or special collections librarians. IT/systems and technical services librarians most often valued other IT/ systems and technical services librarians but were far less likely to value public service 
librarians. Public service librarians are the largest category by department and may have been perceived as the dominant influence in academic libraries.

There was also a low association between respondents' departmental work assignment and the most valued characteristic. The resulting $X^{2}$ of this tabulation produced a $p$-value of 1.5 and $V$ of 0.114 . The residual for one-cell pairing (3.50) made an important contribution to the $X^{2}$ value, occurring between respondents whose departmental assignment was administration and the valued characteristic "Being open to innovation and flexible during periods of change."

Respondents were able to comment on their valued colleagues. Of the 365 comments received, the largest percentage (42\%) elaborated on their choice of characteristic by adding examples to illustrate the characteristic. A number of respondents $(17 \%)$ reflected discomfort with being asked to choose only one valued characteristic, asserting that the valued colleague possessed in equal measure a number of the proffered characteristics. Slightly more than 8 percent of respondents who commented took us to task for not including teaching/instructional ability as a valued characteristic choice.

\section{Limitations}

This study has a number of limitations, some inherent in qualitative research and some resulting from flaws in design and execution. There is always the possibility of sample bias despite the strong measures taken to ensure that the sample pool reflected the known population and then to select a sample at random. Although a pilot survey was administered and wordings of the six valued characteristics were refined, this may not have improved face validity. There is no way of knowing that every respondent interpreted them to have the same meanings. Perhaps the greatest limitation was the low measures of survey reliability. Although the split-half correlation improved significantly from the pilot survey to the final survey (from 0.383 to 0.532 ), confidence in the results is less than desirable. Revising the survey after repeated trials until the reliability measures improved could have corrected the problem, as might increasing the number of items on the survey, but these remedies involve a trade-off in time and effort, both on the part of the researchers and the survey respondents. In addition, the findings could have been misinterpreted by the researchers, or mischaracterized in the study report.

\section{Discussion and Conclusions}

To address the final research question of the study, What, if any, intelligence might the findings suggest for succession planning or for assisting in the transmission of knowledge among academic librarians, especially from career-mature librarians to their younger colleagues prior to leaving the workforce? the findings might suggest

- Early-career librarians valued mid-career librarians more than senior-career librarians, while senior-career librarians valued other senior-career librarians more than mid- or early-career librarians. This has implications for mentorprotégé pairings, and pairings between mid-career and early-career librarians might be more productive than pairings between senior-career and early-career librarians. Senior-career librarians might be advised to devote time to transferring their "deep knowledge of a specific discipline or subject" to mid-career librarians because the latter group reported it as a valued characteristic of senior-career librarians.

- One-third of all respondents identified "Having a strong worth ethic and high job engagement" as the most valued characteristic. Slightly more than 50 percent of respondents in the 31 and under age group chose it as the most valued characteristic, more than either of the other two age groups. These 
results suggest that work ethic and job engagement are universal values and might counter a common social misperception that younger workers are disengaged, less responsible, or less diligent than older workers. This is important because it echoes Kowske, Rasch, and Wile's research as noted earlier in the review of literature, in which it was discovered that generational differences at work are small overall, with regard to work attitudes. There may be a potential gap in the transmission of knowledge from senior librarians to their younger colleagues in terms of "Navigating the political environment to make positive change." Deal found that younger workers in general have the reputation of hating office politics and considering self-interest to be unethical when it interferes with the best interests of the organization, but they also reported recognizing political awareness as important, a skill set they did not have but would like to learn. ${ }^{18}$ Senior-career workers have the reputation of being highly skilled at networking, at creating alliances with influential people, and maintaining a high profile within an organization. Career-mature librarians reported that "Navigating the political environment to make positive change" was not a valued characteristic; they may be unaware of its value to younger colleagues and should increase their efforts to pass this knowledge down.

- Respondents whose departmental assignment was library administration strongly identified the valued characteristic as "Being open to innovation and flexible during periods of change"; overall, 21 percent of total respondents identified this as the valued characteristic. Given the recent challenges of library leadership in terms of social, economic, and institutional change, this finding is not surprising. Developing psychological flexibility, resiliency, and remaining open to new ideas can be challenging. If this is a signal characteristic for library leaders, in what ways can we consciously prepare and select future leadership who will succeed in an environment of continuous change that may last their entire careers? Answering the question is beyond the scope of this study, but it points to an important direction for future research.

- Irrespective of age, respondents valued same-department colleagues over those in other departments. Intradepartmental colleagues have more opportunities for direct observation and for providing reciprocal assistance; they may share a similar workplace culture or values. This finding would support the practice of making promotions from within a department as sound, and it appears that department members can readily identify valued colleagues within their departments.

- The broad Carnegie classification of the institution in which a librarian works does not seem to be associated with the age group of the valued colleague or the valued characteristic of the library colleague. This suggests that libraries might take greater advantage of hiring librarians across/among different types of Carnegie classifications and avoid creating artificial hiring silos. Applicants might consider broadening their job searches to include vacancies in all types of Carnegie-classified institutions. Libraries might consider sharing professional development opportunities or encouraging cross-institutional mentor/protégé pairings irrespective of their size and purpose.

The findings of this study may have some value for other tech-heavy professions that are also experiencing issues of generational change. Many types of organizations aside from academic libraries are seeking to balance the experience and "wisdom of the elders" with newer professionals' capacity for instant change and appetite for new skill acquisition. 


\section{Final Thoughts}

The impetus for this study arose from personal curiosity about what we, as Boomers and career- mature librarians, might have to offer our early- and mid-career colleagues as we plan to retire and leave the workforce. We were pleased to learn that many of the characteristics valued by "our" generation were shared by others; especially that respect for strong work ethic and high job engagement were universal values rather than the exclusive property of Boomers. We were surprised to find that the Carnegie level of the institution in which librarians spent the majority of the careers, however short or long those careers have been, didn't seem to make a difference in who was valued or why they were valued. We were not surprised to find that librarians most often valued an immediate departmental colleague, but we were concerned to discover the unhealthy roots of a divide between public services librarians and IT/systems and technical services librarians in the evidence. If there is such a divide, it can no longer be afforded.

Paradoxically, senior-career librarians did not appear to value what they should be in the best position to transmit to their younger colleagues-how to navigate the political environment to make positive change. Understanding how institutions of higher education and their libraries operate in terms of governance, and especially in terms of gaining and using organizational power for the good of the library, may be very important to convey, especially in the current hostile environment. Senior-career librarians should not undervalue their skills in this arena, or consider themselves anachronistic, but might serve others by passing down what they have learned about organizational politics from years of experience.

In examining empirically what is valued by workplace colleagues, we sought to provide a baseline foundation for understanding cross-generational workforce issues and to find potentials for academic librarians of any age or career stage to contribute to the well-being of their libraries. Further and more extensive research on new and early-career librarians would be particularly enlightening, as would developing a better understanding of the benefits that can be transmitted by mid-career librarians who appear to be their preferred mentors.

Questions remain regarding the value of instructional skill in the mix, and attempts to tease apart the importance of the instructional function within public services and the importance of teaching as a part of mentoring could be beneficial. It would also be useful to explore valuing as opposed to emulating; that is, if librarians who indicate that they value "strong work ethic and high job engagement" consciously emulate the associated behaviors.

\section{Notes}

1. Lynne C. Lancaster, "The Click and Clash of Generations," Library Journal 128, no. 17 (2003): 36-39; Sue Hutley and Terena Solomons, "Generational Change in Australian Librarianship: Viewpoints from Generation X," paper presented at the Australian Library and Information Association Biennial Conference, Gold Coast, Queensland, Australia, September 21-24, 2004; Rachel Singer Gordon, "Next Generation Librarianship," American Libraries 37, no. 1 (2006): 36-38; Jason Martin, "I Have Shoes Older Than You: Generational Diversity in the Library," Southeastern Librarian 54, no. 3 (2006): 4-11; Melanie Chu, "Ageism in Academic Librarianship," Electronic Journal of Academic and Special Librarianship 10, no. 2 (2009), available online at http://southernlibrarianship. icaap.org [accessed 10 March 2013].

2. Jean M. Twenge, "A Review of the Empirical Evidence on Generational Differences in Work Attitudes," Journal of Business and Psychology 25 (2010): 201-10.

3. Neil Howe and William Strauss, Generations: The History of America's Future, 1584-2069 (New York: HarperCollins, 1991); Neil Howe and William Strauss, Millennials Rising (New York: Vintage, 2000). 
4. Karen Way Smola and Charlotte D. Sutton, "Generational Differences: Revisiting Generational Work Values for the New Millennium," Journal of Organizational Behavior 23 (2002): $363-82$.

5. Keith Macky, Dianne Gardner, and Stewart Forsyth, "Generational Differences at Work: Introduction and Overview," Journal of Managerial Psychology 23, no. 1 (2008): 857-61.

6. Brenda J. Kowske, Rena Rasch, and Jack Wile, "Millennials' (Lack of) Attitude Problem: An Empirical Examination of Generational Effects on Work Attitudes," Journal of Business and Psychology (Special Issue: Millennials and the World of Work: What You Didn't Know You Didn't Know) 25, no. 2 (2010): 265-79.

7. Gail Munde, “Considerations for Managing an Increasingly Intergenerational Workforce in Libraries," Library Trends 59, no. 1-2 (2010): 88-108.

8. Sara D. Smith and Quinn Galbraith, "Motivating Millennials: Improving Practices in Recruiting, Retaining, and Motivating Younger Library Staff," Journal of Academic Librarianship 38, no. 3 (May 2012): 135-44.

9. Laura L. Jobe, "Generational Differences in Work Ethic between Baby Boomers, Generation X, and Millennial Registered Nurses" (Ph.D. diss., University of Arkansas for Medical Sciences, 2013), available online at http://search.proquest.com.jproxy.lib.ecu.edu/docview/1500560140?ac countid=10639 [accessed 12 May 2014].

10. ACRL Research Planning and Review Committee, “Environmental Scan 2010," available online at www.ala.org/acrl/sites/ala.org.acrl/files/content/publications/whitepapers/EnvironmentalScan201.pdf [accessed 22 December 2013]; Association of Southeastern Research Libraries Education Committee, "Shaping the Future: ASERL's Competencies for Research Librarians," Atlanta, Ga., 2001, available online at www.aserl.org/wp-content/uploads/2011/07/competencies. pdf [accessed 22 December 2013]; American Library Association, "ALA's Core Competences of Librarianship," available online at www.ala.org/educationcareers/sites/ala.org.educationcareers/ files/content/careers/corecomp/corecompetences/finalcorecompstat09.pdf [accessed 22 December 2013].

11. National Center for Education Statistics, "Academic Libraries: 2010 First Look," Table 7, 2011, available online at http://nces.ed.gov/pubsearch/pubsinfo.asp?pubid=2012365 [accessed 22 December 2013].

12. Information Today. American Library Directory 2011-2012. 64th ed. (Medford, N.J., 2012).

13. American Library Association, Office of Research and Statistics, Diversity Counts (Chicago, Ill., 2007).

14. Barbara Moran, JoAnne Marshall, and Susan Rathbun-Grubb, "The Academic Library Workforce: Past, Present and Future," Library Trends 59, no. 1-2 (2010): 208-19. 2010)

15. Association of Research Libraries, ARL Annual Salary Survey 2009-2010 (Washington, D.C.,

16. Donald King, Jose-Marie Griffiths, The Future of Academic Librarians: A Ten-Year Forecast of Librarian Supply and Demand, Library Assessment Conference, Baltimore, Md., October 25-27, 2010 .

17. National Center for Education Statistics, 2011.

18. Jennifer Deal, Retiring the Generation Gap: How Employees Young and Old Can Find Common Ground (San Francisco: John Wiley \& Sons and Center for Creative Leadership, 2007). 